\title{
ПОИСК НОВЫХ ИНГИБИТОРОВ БАКТЕРИАЛЬНОГО БЕЛКА FtsZ
}

\author{
К.Л. Обыденнов ${ }^{1}$, Т.А. Калинина', Н.А. Галиева', М.А. Яшная", \\ Т.В. Берёзкина', Т.В. Глухарева ${ }^{1,3}$, В.А. Бакулев' \\ ${ }^{1}$ Химико-технологический институт, Уральский федеральный университет, \\ 620002, Россия, Екатеринбург, Мира, 19. \\ ${ }^{2}$ Институт естественных наук и математики, Уральский федеральный университет, \\ 620002, Россия, Екатеринбург, Куйбышева, 48. \\ ${ }^{3}$ Институт органического синтеза им. И.Я. Постовского, \\ УрО РАН, 620990, Россия, Екатеринбург, С. Ковалевской/Академическая, 20/22.
}

DOI: 10.19163/MedChemRussia2021-2021-253

E-mail:k.l.obydennov@urfu.ru

Бактериальная инфекция представляет большую опасность для здоровья человека. В настоящее время многие бактериальные штаммы стали устойчивыми к существующим антибиотикам, что делает лечение неэффективным. Поэтому существует острая необхо-димость в разработке новых антибактериальных средств с новыми механизмами действия, которые могут решить проблему распространения резистентности бактерий. Процесс деления бактериальных клеток - это новая и привлекательная цель для разработки новых антибактериальных препаратов. Деление клеток - важнейшее событие в жизни каждого организма. Нитевидный термочувствительный белок Z (FtsZ), гомолог тубулина, является наиболее многочисленным и высококонсервативным белком в делении клеток почти всех бактерий, играя важную роль в делении прокариотических клеток.

Целью данного исследования был поиск новых антибактериальных соединений - ингибиторов бактериального белка FTsZ - с использованием компьютерных методов исследования биологической активности веществ (in silico) и биологического скрининга (in vitro). Методами QSAR и фармакофорных теорий с использованием данных о структуре известных ингибиторов FtsZ и пространственном строении белка-рецептора, сделан прогноз антибактериальной активности библиотеки соединений - производных бензимидазола, бензотиазола и бензоксазола, и произведен отбор потенциальных антибактериальных веществ - ингибиторов FtsZ.

В результате оценки антибактериальной активности 42 соединений in vitro были обнаружены 2 соединения с высокой антибактериальной активностью в отношении широкого ряда грамположительных и грамотрицательных бактерий. В ходе молекулярного докинга были выявлены особенности взаимодействия исследуемых веществ с белком FtsZ Staphylococcus aureus в полости связывания, расположенной рядом с петлей Т7 и С-концом. 